\title{
The $\delta$-Opioid Receptor Agonist (+)BW373U86 Regulates BDNF mRNA Expression in Rats
}

\author{
Mary M Torregrossa', Ceylan Isgor ${ }^{2}$, John E Folk ${ }^{3}$, Kenner C Rice ${ }^{3}$, Stanley J Watson ${ }^{1,2}$ \\ and James $H$ Woods*, W $^{2}$ \\ 'Neuroscience Doctoral Program, University of Michigan, Ann Arbor, MI, USA; ${ }^{2}$ Mental Health Research Institute, University of Michigan, Ann \\ Arbor, MI, USA; ${ }^{3} \mathrm{NIDDK}, \mathrm{NIH}, \mathrm{DHHS}$, Bethesda, MD, USA; ${ }^{4}$ Department of Pharmacology, University of Michigan, Ann Arbor, MI, USA
}

\begin{abstract}
$\delta$-Opioid receptor agonists have antidepressant-like effects in behavioral models of depression. Chronic administration of classical antidepressants upregulates mRNA expression of brain-derived neurotrophic factor (BDNF) and its high-affinity tyrosine kinase receptor, TrkB in the frontal cortex and hippocampus of rats. Increases in BDNF and TrkB levels are thought to be important for the therapeutic effects of these drugs. Therefore, we examined the ability of the $\delta$-opioid receptor agonist $(+) B W 373 \cup 86$ to regulate BDNF and TrkB mRNA expression in frontal cortex, hippocampus, as well as, basolateral amygdala, endopiriform nucleus, and primary olfactory cortex. At $3 \mathrm{~h}$ after a single administration of $(+)$ BW373U86 animals were killed and BDNF and TrkB mRNA levels were examined by in situ hybridization. BDNF mRNA levels produced by $(+)$ BW373U86 were compared to acute administration of the antidepressants desipramine and bupropion. A behaviorally antidepressant dose of $10 \mathrm{mg} / \mathrm{kg}(+) \mathrm{BW} 373 \mathrm{U} 86$ increased BDNF mRNA expression in all regions examined; a smaller dose of $(+) B W 373 \cup 86(\mathrm{l} \mathrm{mg} / \mathrm{kg})$ significantly increased BDNF mRNA expression only in frontal cortex. The $\delta$-opioid receptor antagonist naltrindole blocked $(+)$ BW373U86-mediated increases in BDNF mRNA expression. In addition, tolerance developed to increased BDNF mRNA expression with repeated injection, except in frontal cortex. Midazolam was administered to some animals to prevent the convulsions produced by $(+)$ BW373U86, but midazolam did not block $\delta$-opioid receptormediated increases in BDNF mRNA expression in frontal cortex, hippocampus, or amygdala. Unlike desipramine and bupropion, $(+)$ BW373U86 upregulated BDNF mRNA expression acutely (within $3 \mathrm{~h}$ after a single administration). These data support the concept that $\delta$-opioid receptor agonists may have antidepressant potential, and could be good targets for the development of faster-acting antidepressants.

Neuropsychopharmacology (2004) 29, 649-659, advance online publication, 26 November 2003; doi: I 0. I 038/sj.npp. I 300345
\end{abstract}

Keywords: $\delta$-opioid receptor; BDNF; TrkB; in situ hybridization; antidepressant; (+)BW373U86

\section{INTRODUCTION}

Depression is a serious illness affecting millions of people, and though there are many pharmacological treatments available, there is still a need to find therapeutics that effectively treat a larger population of patients with fewer adverse side effects and that work quickly. Current antidepressants must be administered for weeks before they begin to have a maximum beneficial effect. The reason for the long delay between onset of treatment and therapeutic effect is not well understood; however, recent findings suggest that chronic antidepressant treatment

\footnotetext{
*Correspondence: JH Woods, Department of Pharmacology, University of Michigan Medical School, I30I MSRB III, Ann Arbor, MI 48 109-0632, USA, Tel: + I (734) 764 9133, Fax: + I (734) 764 7I I8, E-mail: jhwoods@umich.edu

Received 23 April 2003; revised 23 September 2003; accepted 06 October 2003

Online publication: 9 October 2003 at http://www.acnp.org/citations/ Npp I0090303 |74/default.pdf
}

alters gene expression and synaptic organization, and this leads to improved mood (see reviews Vaidya and Duman, 2001; Duman et al, 1997, 2000; Duman, 2002).

The neurotrophin, brain-derived neurotrophic factor (BDNF), and its receptor, a tyrosine kinase receptor (TrkB), have been implicated as potential mediators of these longterm synaptic changes (Duman et al, 1997). BDNF is a neurotrophin that supports neuronal growth and survival during development and in the adult nervous system, and has been shown to regulate synaptic plasticity (reviewed by McAllister et al, 1999). BDNF promotes dendritic sprouting and can protect neurons from atrophy and death due to stress or other injury (Duman et al, 2000). BDNF and TrkB mRNAs are both upregulated by chronic antidepressant administration and by repeated electroconvulsive shock (ECS) in the frontal cortex and hippocampus (Nibuya et al, 1995). Additionally, BDNF injected directly into the midbrain (Siuciak et al, 1997) and hippocampus (Shirayama et al, 2002) has antidepressant-like effects in behavioral models of depression. Therefore, increased BDNF activity is 
likely to be important for the therapeutic effects of antidepressants.

The $\delta$-opioid receptor system is a novel neurotransmitter system that has been implicated in depression; $\delta$-opioid receptors are present in cortical and limbic regions, suggesting that they may play a role in modulating cognitive and emotional function (Cahill et al, 2001). Indeed, mice lacking functional $\delta$-opioid receptors demonstrate increased anxiety-like behaviors in the light-dark box and elevated plus-maze and depressive-like behaviors in the forced swim test, indicating that the $\delta$-opioid receptor system may be important for regulating normal emotional states (Filliol et al, 2000). Broom et al (2002a) found that the nonpeptidic $\delta$-opioid receptor agonists (+)BW373U86 and SNC80 produce antidepressant-like effects in the rat forced swim test. In addition, RB101, a drug that inhibits the catabolism of enkephalins, endogenous $\delta$-opioid receptor ligands, has antidepressant effects in a learned helplessness procedure (Tejedor-Real et al, 1998). These data suggest that the $\delta$-opioid receptor system may be an interesting target in the treatment of depression; however, the mechanisms underlying these antidepressant effects are unknown.

The present study examined whether an antidepressant dose of $(+)$ BW373U86 would lead to an acute increase in BDNF or TrkB mRNA in the hippocampus and frontal cortex, two regions that have been implicated in the action of known antidepressant drugs. Desipramine and bupropion were also given acutely for comparative purposes. The amygdala, endopiriform nucleus, and primary olfactory cortex were also examined for the role these regions might play in the convulsions produced by $\delta$-opioid receptor agonists (Comer et al, 1993; Broom et al, 2002b). The selective $\delta$-opioid receptor antagonist naltrindole (NTI) was given to determine if increases in BDNF mRNA were mediated through the $\delta$-opioid receptor. In addition, midazolam was given to a group of animals to determine if the convulsions produced by $(+)$ BW373U86 are necessary for $\delta$-opioid receptor-mediated changes in BDNF mRNA expression. Another group of animals was made tolerant to the convulsive effects to determine if tolerance developed to increases in BDNF mRNA. Finally, we examined whether bupropion has acute antidepressant effects in the forced swim test, as has already been shown for $(+)$ BW373U86 and desipramine (Broom et al, 2002a, b).

\section{MATERIALS AND METHODS}

\section{Animals}

Male Sprague-Dawley rats weighing 250-300 g upon delivery (Harlan Sprague-Dawley, Indianapolis, IN) were housed three per cage and allowed ad libitum access to food and water. Animals were kept on a 12-h light/dark cycle with lights on at 0630 and a room temperature of $21^{\circ} \mathrm{C}$. Experiments were carried out in accordance with the Declaration of Helsinki and with the Guide for the Care and Use of Laboratory Animals as adopted and promulgated by the National Institutes of Health. The study protocols were approved by the University of Michigan University Committee on the Use and Care of Animals.

\section{Drugs}

$(+)$ BW373U86 - 2HCl $((+)-4-[(\alpha \mathrm{R})-[(2 S, 5 R)$-2,5-dimethyl4-(2-propenyl)-1-piperazinyl](3-hydroxyphenyl)methyl]$\mathrm{N}, \mathrm{N}$-diethylbenzamide dihydrochloride) was synthesized by modifications of published protocols (Bishop and McNutt, 1995), and was dissolved in sterile water. Desipramine and bupropion (Sigma, St Louis, MO, USA) were dissolved in sterile water. Naltrindole hydrochloride (Dr J Lewis, University of Bath, UK) and midazolam (Bedford Laboratories, Bedford, OH, USA) were dissolved in sterile saline.

\section{Experimental Treatment}

In experiment 1 , animals were given a single injection of sterile water vehicle, $1 \mathrm{mg} / \mathrm{kg}$, or $10 \mathrm{mg} / \mathrm{kg}(+)$ BW373U86 subcutaneously (s.c.) ( $n=4$ per group). These animals were used to determine if $(+)$ BW373U86 could dose-dependently regulate either BDNF or TrkB mRNA expression levels. Another group of animals was given sterile water vehicle, $15 \mathrm{mg} / \mathrm{kg}$ desipramine, or $32 \mathrm{mg} / \mathrm{kg}$ bupropion intraperitoneally (i.p.) ( $n=4$ per group), in order to compare BDNF expression in response to acute administration of two different classes of antidepressants.

Experiment 2 was conducted to verify that $32 \mathrm{mg} / \mathrm{kg}$ bupropion has acute antidepressant behavioral effects in the forced swim test. Animals received an i.p. injection of sterile water vehicle or $32 \mathrm{mg} / \mathrm{kg}$ bupropion ( $n=6$ per group) $30 \mathrm{~min}$ prior to being tested in a modified forced swimming test.

In experiment 3 , using a $2 \times 2$ experimental design, animals were injected with saline or $10 \mathrm{mg} / \mathrm{kg}$ NTI s.c., $15 \mathrm{~min}$ prior to an injection of sterile water vehicle or $10 \mathrm{mg} /$ $\mathrm{kg}(+)$ BW373U86 s.c. ( $n=4$ per group).

Experiment 4 was carried out in the same manner as experiment 3 . Using a $2 \times 2$ experimental design animals were injected with saline or $0.5 \mathrm{mg} / \mathrm{kg}$ midazolam s.c., $15 \mathrm{~min}$ prior to an injection of sterile water vehicle or $10 \mathrm{mg} /$ $\mathrm{kg}(+)$ BW373U86 s.c. The midazolam plus (+)BW373U86 group contained six animals, and all other groups contained four. In experiments 1,3 , and 4 , animals were monitored for convulsions in clean cages (one animal per cage) for $20 \mathrm{~min}$ following injection, and were then placed back in their home cages. At $3 \mathrm{~h}$ after the last injection, animals were killed by rapid decapitation and their brains were removed and frozen in isopentane at $-40^{\circ} \mathrm{C}$, and were stored at $-80^{\circ} \mathrm{C}$.

In experiment 5 , to determine if tolerance develops to any increases in BDNF or TrkB mRNA, animals received two injections $24 \mathrm{~h}$ apart. Broom et al (2002b) previously demonstrated that $10 \mathrm{mg} / \mathrm{kg}(+) B W 373$ U86 produces tolerance to convulsive effects for up to $24 \mathrm{~h}$. The first group received an injection of sterile water vehicle on both days 1 and 2, the second group received an injection of $10 \mathrm{mg} / \mathrm{kg}(+)$ BW373U86 on day 1 and an injection of vehicle on day 2 , and the third group received an injection of $10 \mathrm{mg} / \mathrm{kg}(+)$ BW373U86 on both days 1 and $2(n=4$ per group). All animals were monitored for convulsions for 20 min after injection on both days. At $3 \mathrm{~h}$ after the injection on day 2, the animals were killed and their brains taken as above. Brains were sectioned at $14 \mu \mathrm{m}$ on a cryostat and were thaw mounted onto poly-L-lysine subbed slides. Slides 
were stored at $-80^{\circ} \mathrm{C}$ until they were processed for in situ hybridization.

\section{In Situ Hybridization Histochemistry}

BDNF and TrkB mRNA levels were determined by a doublelabel in situ hybridization with a $\left[{ }^{35} \mathrm{~S}\right] \mathrm{BDNF}$ or TrkB RNA probe. The rat TrkB cDNA (described by Middlemas et al, 1991) was donated by Dr Hunter (The Salk Institute). The rat BDNF cDNA (described by Isackson et al, 1991) was donated by Drs Gall and Lauterborn (University of California, Irvine).

Sections were fixed in $4 \%$ paraformaldehyde for $1 \mathrm{~h}$. Then, they were washed three times in $2 \times$ SSC $(300 \mathrm{mM}$ $\mathrm{NaCl}, 30 \mathrm{mM}$ sodium citrate), placed in a solution consisting of $0.25 \%$ acetic anhydride in $0.1 \mathrm{M} \mathrm{TEA}, \mathrm{pH} 8.0$, at room temperature for $10 \mathrm{~min}$, washed in distilled water, and dehydrated in progressively graded alcohols (50, 70, 80, 95, $100 \%)$. The sections were then labeled with the BDNF or TrkB cRNA probe. The probe was radioactively labeled in a reaction containing $1 \mu \mathrm{g}$ BDNF or TrkB antisense linearized plasmid DNA, $5 \times$ transcription buffer, $125 \mu \mathrm{Ci}$ each of $\left[{ }^{35}\right.$ S]UTP and $\left[{ }^{35} \mathrm{~S}\right] \mathrm{CTP}, 150 \mu \mathrm{M}$ each of ATP and GTP, $12.5 \mathrm{mM}$ dithiothreitol, $20 \mathrm{U}$ RNase inhibitor, and $6 \mathrm{U}$ of T3 polymerase. The reaction was carried out for $90 \mathrm{~min}$ at $37^{\circ} \mathrm{C}$. The probes were separated from unincorporated nucleotides using BIORAD kit: MicroBioSpin 6 Chromatography Columns (Bio-Rad Laboratories, CA). The probes were diluted in a hybridization buffer to obtain $1.5 \times 10^{6} \mathrm{dpm} /$ $80 \mu \mathrm{l}$. The sections were then coverslipped and allowed to hybridize at $55^{\circ} \mathrm{C}$ for $16 \mathrm{~h}$. At this time, coverslips were removed and the slides were washed twice in $2 \times$ SSC. Then, sections were incubated in RNase for $1 \mathrm{~h}$ at $37^{\circ} \mathrm{C}$, washed in decreasing concentrations of SSC $(2 \times, 1 \times, 0.5 \times, 0.25 \times)$, and washed in $0.1 \times \mathrm{SSC}$ at $65^{\circ} \mathrm{C}$ for $1 \mathrm{~h}$. Sections were then rinsed in distilled water and dehydrated through graded alcohols. Control slides incubated in RNase before processing were run simultaneously. The slides were developed on Kodak XAR film (Eastman Kodak, Rochester, NY) for 14 days for BDNF and 5 days for TrkB.

\section{Quantification of Radioactive Signal}

BDNF and TrkB mRNA levels were quantified using NIH Image (Scion Image Corp.) software. BDNF mRNA expression was examined in frontal cortex; the CA1, the CA3, and the dentate gyrus regions of hippocampus; the basolateral amygdaloid complex; the endopiriform nucleus; and primary olfactory cortex. TrkB mRNA expression was examined in frontal cortex and the CA1, CA3, and dentate gyrus regions of hippocampus. Each brain region was analyzed by creating an outline around the region and measuring both the left and right sides of the brain and from rostral-caudal sections $100-200 \mu \mathrm{m}$ apart. At least six sections per region per rat were quantified. The signal measurements were corrected for background and were determined as the mean radioactive intensity per pixel for that region. These signal values for each section were then averaged to obtain the mean signal for each region in each rat. These data points were then averaged per group and compared statistically.

\section{Forced Swim Test}

The forced swim test was conducted essentially as described by Broom et al (2002b). Rats were videotaped from above during a $15-\mathrm{min}$ swim period in a cylindrical Plexi-glas container $(46 \mathrm{~cm}$ tall $\times 20 \mathrm{~cm}$ diameter $)$, filled to $30 \mathrm{~cm}$ with $25^{\circ} \mathrm{C}( \pm 1)$ water. Cylinders were cleaned and fresh water added between each rat. An observer blind to treatment scored the videotapes. Behaviors were scored every $5 \mathrm{~s}$ for the entire $15-\mathrm{min}$ period and were classified as immobility, swimming, or climbing. Immobility, swimming, and climbing were defined as described by Broom et al (2002a,b).

\section{Statistical Analysis}

In experiments 3 and 4, a two-way ANOVA was conducted and Tukey's post hoc test was used to determine differences between groups. In all other experiments, one-way ANOVA and Tukey's post hoc test were used to determine statistical differences between groups where $P<0.05$ was considered significant.

\section{RESULTS}

\section{Experiment 1. A Single Injection of $(+) B W 373$ U86 Upregulates BDNF but not TrkB mRNA Expression, While Desipramine and Bupropion DownRegulate BDNF MRNA}

In the first set of experiments we found that $(+)$ BW373U86 at doses of 1 and $10 \mathrm{mg} / \mathrm{kg}$ significantly increased BDNF mRNA expression in the frontal cortex in a dose-dependent manner (Figure 1). BDNF mRNA levels were also significantly increased in the CA3 region of hippocampus and tended to increase in the CA1 region of hippocampus, but only at a dose of $10 \mathrm{mg} / \mathrm{kg}$ (Figure 1). In addition, BDNF mRNA levels were significantly increased in the basolateral complex of the amygdala, the endopiriform nucleus, and in primary olfactory cortex, after injection of $10 \mathrm{mg} / \mathrm{kg}$ $(+) B W 373$ U86 (Figure 2). Desipramine and bupropion both significantly decreased BDNF mRNA expression in the CA1 and dentate gyrus regions of the hippocampus (Figure 3). Desipramine also significantly decreased BDNF mRNA expression in frontal cortex (Figure 3). TrkB mRNA levels were not significantly different between groups in any brain region examined in response to 1 or $10 \mathrm{mg} / \mathrm{kg}$ $(+) B W 373$ U86 (Figure 4). TrkB mRNA levels were not examined after treatment with desipramine or bupropion. RNase-treated controls showed no specific binding of the probes (data not shown).

\section{Experiment 2. Acute Bupropion Decreases Immobility in the Forced Swim Test: An Indication of Antidepressant Activity}

Both $(+)$ BW373U86 and desipramine reduce immobility in the forced swim test after a single administration (Broom et al, 2002b). Given that result we examined BDNF mRNA expression after a single injection of $(+) B W 373$ U86, to compare it to known antidepressants that also have acute actions in the forced swim test. We also wanted to compare $(+) B W 373$ U86 to an antidepressant like bupropion, which 

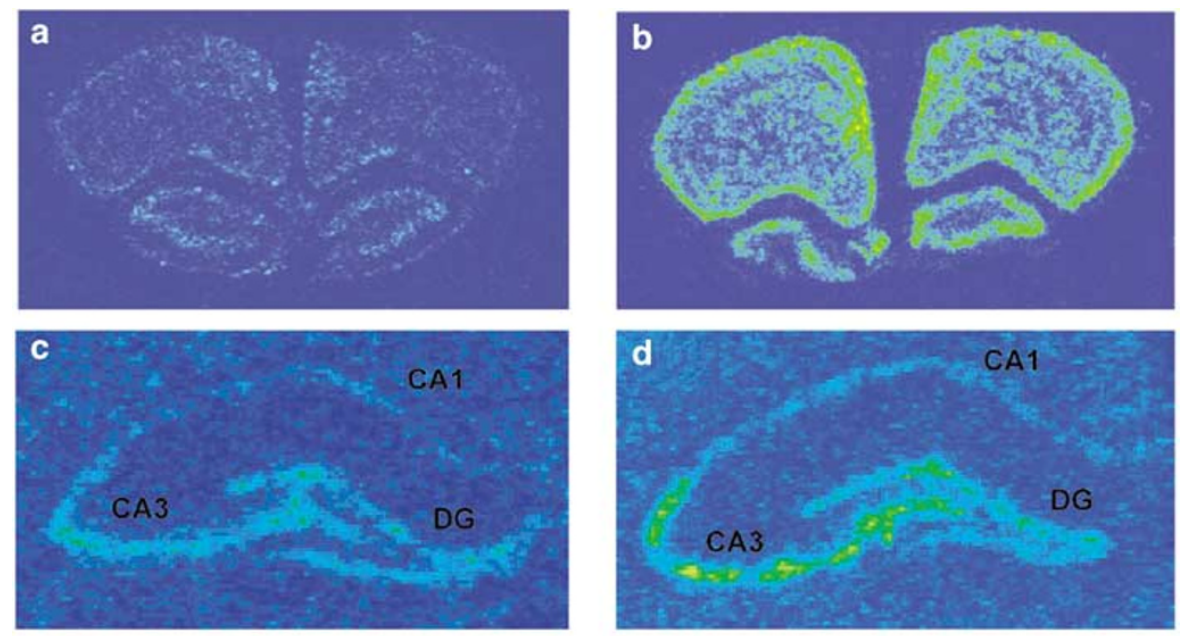

e BDNF mRNA Expression

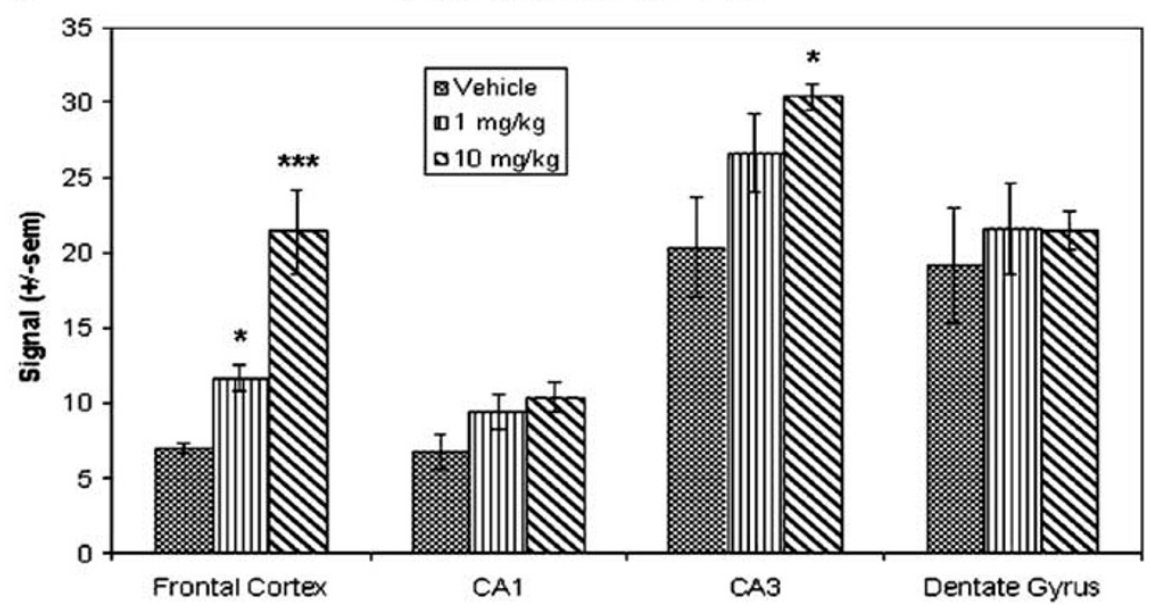

Figure I BDNF mRNA expression in frontal cortex and hippocampus. (a-d) Photomicrographs from X-ray films exposed for 14 days after in situ hybridization with the antisense cRNA probe to rat BDNF mRNA. (a) Section of frontal cortex taken from a vehicle-treated animal. (b) Section of frontal cortex taken from an animal treated with $10 \mathrm{mg} / \mathrm{kg}(+)$ BW373U86 (BW) s.c. (c) Example of hippocampal section taken from a vehicle-treated animal. (d) Hippocampus of an animal treated with $10 \mathrm{mg} / \mathrm{kg}$ BW. (e) Quantification of BDNF mRNA signal in the frontal cortex and hippocampal regions expressed as mean \pm SEM. In frontal cortex, I and $10 \mathrm{mg} / \mathrm{kg}$ BW significantly increased BDNF mRNA expression. BW at both doses tended to increase BDNF in CA I and $10 \mathrm{mg} / \mathrm{kg}$ BW did significantly increase BDNF mRNA levels in CA3. There was no effect of BW on BDNF mRNA expression in dentate gyrus, *P $<0.05$, ***** $P<0.001$.

primarily acts as a dopamine reuptake inhibitor, because administration of $(+)$ BW373U86 results in dopaminedependent locomotor stimulation (Spina et al, 1998). Therefore, we examined whether bupropion has acute antidepressant effects in the forced swim test. Bupropion significantly decreased counts of immobility during the 15min swim; with a concomitant significant increase in swimming behavior (Figure 5).

\section{Experiment 3. Increases in BDNF mRNA Induced by $(+) B W 373 U 86$ are $\delta$-Opioid Receptor Mediated}

The $\delta$-opioid receptor antagonist NTI, while having no effects on BDNF mRNA expression alone, blocked increases in BDNF mRNA produced by (+)BW373U86 (Figure 6). This result was observed in every brain region examined. Unlike the above experiment, (+)BW373U86 significantly increased BDNF mRNA expression in the CA1 region of hippocampus, but not in the CA3. Generally, increases in
BDNF mRNA expression in hippocampus were of a lower magnitude and were less consistent than those seen in frontal cortex and the amygdaloid and piriform regions.

\section{Experiment 4. $\delta$-Opioid Receptor-Mediated Increases in BDNF mRNA Expression are Convulsion Dependent in Some Brain Regions}

Midazolam given prior to $10 \mathrm{mg} / \mathrm{kg}(+)$ BW373U86 blocked all convulsions, while $100 \%$ of animals treated with vehicle prior to the same dose of $(+)$ BW373U86 convulsed (data not shown). (+)BW373U86 alone significantly increased BDNF mRNA expression in frontal cortex, CA1, CA3, basolateral amygdala, endopiriform nucleus, and olfactory cortex (Figure 7). When midazolam was given prior to $(+) B W 373$ U86, BDNF mRNA levels were significantly increased in frontal cortex and in the basolateral amygdala when compared to vehicle controls, though the increase in frontal cortex was significantly less than when 

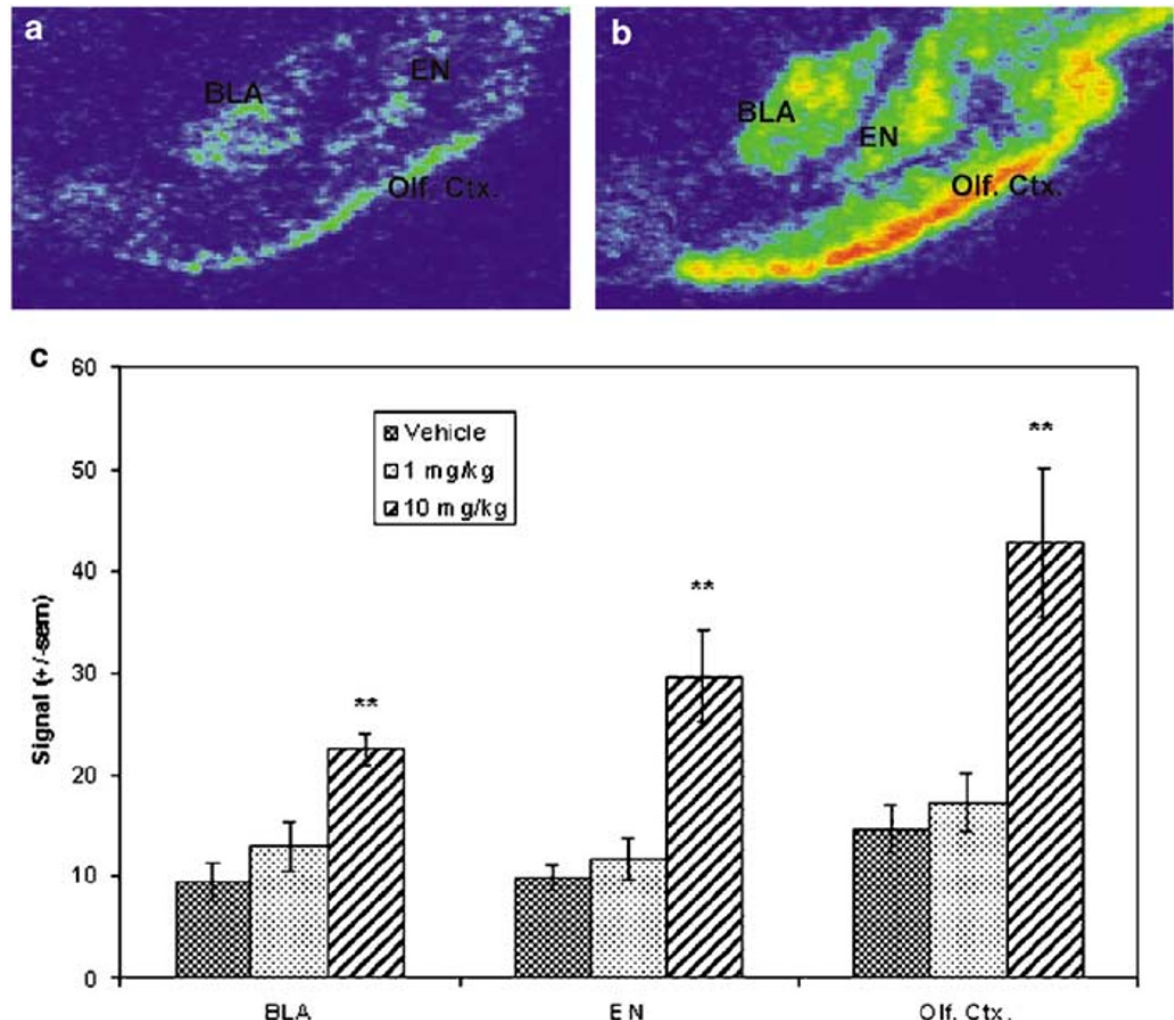

Figure 2 BDNF mRNA expression in basolatera amygdala, endopiriform nucleus, and primary olfactory cortex. (a-b) Photomicrographs from x-ray films exposed for 14 days after in situ hybridization with the antisense cRNA probe to rat BDNF mRNA. Photos show sections of rat brain through the basolateral amygdaloid complex (BLA), endopiriform nucleus (EN), and the primary olfactory cortex or piriform cortex (Olf. Ctx.). (a) Section from a vehicle-injected animal. (b) Section from an animal injected with $10 \mathrm{mg} / \mathrm{kg}(+) B W 373$ U86 (BW) s.c. (c) Quantification of BDNF mRNA signal in BLA, EN, and Olf. Ctx. expressed as mean \pm SEM. In all three brain regions, $10 \mathrm{mg} / \mathrm{kg}$ BW significantly increased BDNF mRNA expression, $* * P<0.01 ; \mathrm{I} g \mathrm{mg} / \mathrm{kg}$ BW had no effect.

$(+)$ BW373U86 was given alone $(P<0.001)$. In addition, animals given midazolam and $(+)$ BW373U86 had significantly increased BDNF mRNA levels in frontal cortex, CA1, CA3, basolateral amygdala, and endopiriform nucleus compared to animals given midazolam alone (Figure 7). Midazolam alone tended to decrease BDNF mRNA expression in most brain regions, and did so significantly in the CA1 region of hippocampus. The olfactory cortex was the only region where midazolam completely blocked $\delta$-opioid receptor-mediated increases in BDNF mRNA expression.

\section{Experiment 5. Tolerance Development to $\delta$-opioid Receptor-Mediated Increases in BDNF mRNA}

A single injection of $10 \mathrm{mg} / \mathrm{kg}(+)$ BW373U86 increases BDNF mRNA expression and causes a brief, nonlethal convulsion; a second injection of $10 \mathrm{mg} / \mathrm{kg}(+) B W 373 \mathrm{U} 86$, $24 \mathrm{~h}$ later, does not produce a convulsion, suggesting tolerance development as previously reported in mice (Comer et al, 1993; Hong et al, 1998) and rats (Broom et al, 2002b). Repeated injection of (+)BW373U86 in this experiment produced tolerance to convulsions and tolerance to increases in BDNF mRNA expression in the hippocampus, basolateral amygdala, endopiriform nucleus, and primary olfactory cortex (data not shown). However, BDNF mRNA levels can be significantly increased after repeated administration of $(+)$ BW373U86 in the frontal cortex, but to a lesser extent than is seen with a single administration (Figure 8). In addition, animals receiving $10 \mathrm{mg} / \mathrm{kg}(+)$ BW373U86 followed by a vehicle injection $24 \mathrm{~h}$ later, showed no increases in BDNF mRNA in any region, indicating that the upregulation seen after $3 \mathrm{~h}$ does not last for over $24 \mathrm{~h}$.

\section{DISCUSSION}

The $\delta$-opioid receptor agonist (+)BW373U86 significantly upregulated BDNF mRNA expression in the frontal cortex, basolateral amygdala, endopiriform nucleus, and primary olfactory cortex. (+)BW373U86 also increased BDNF mRNA in the CA1 and CA3 of hippocampus, but to a lesser extent, and less consistently across experiments. BDNF mRNA was upregulated within $3 \mathrm{~h}$ of a single administration of $(+)$ BW373U86, unlike the antidepressants, desipramine and bupropion, which actually decreased BDNF mRNA when given acutely.

\section{Comparison of $(+)$ BW373U86 to other Antidepressants}

Unlike known antidepressant drugs, including desipramine and bupropion reported here, $(+)$ BW373U86 rapidly increased BDNF mRNA expression in several brain regions, most notably in the frontal cortex. This suggests the possibility that $\delta$-opioid receptor agonists could be fastacting antidepressants. Previous reports have shown that a 

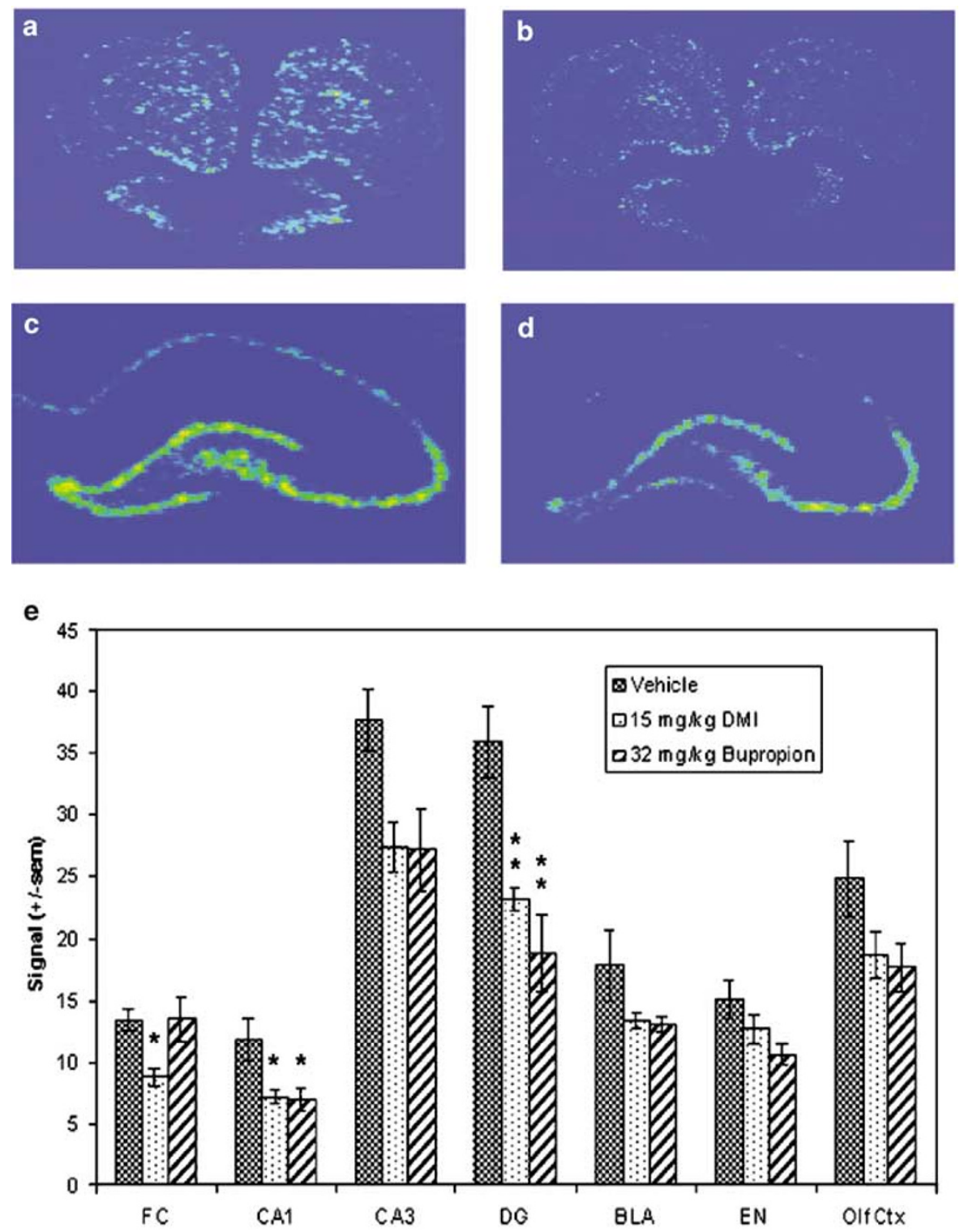

Figure 3 BDNF mRNA expression across brain regions in response to acute desipramine or bupropion. (a-d) Photomicrographs from $x$-ray films exposed for 14 days after in situ hybridization with the antisense cRNA probe to rat BDNF mRNA. (a) Section of frontal cortex taken from a vehicle-treated animal. (b) Section of frontal cortex taken from an animal treated with $15 \mathrm{mg} / \mathrm{kg}$ desipramine (DMI) i.p. (c) Example of hippocampal section taken from a vehicle-treated animal. (d) Hippocampus of an animal treated with $15 \mathrm{mg} / \mathrm{kg}$ DMl. (e) Quantification of BDNF mRNA signal in the frontal cortex, hippocampal regions, BLA, EN, and Olf. Ctx. expressed as mean \pm SEM, in animals receiving DMl as shown, or $32 \mathrm{mg} / \mathrm{kg}$ bupropion i.p. Desipramine significantly decreased BDNF mRNA expression in frontal cortex, and both desipramine and bupropion significantly decreased BDNF mRNA in CAI and CA3 of hippocampus compared to vehicle controls, $* P<0.05$, $* * P<0.0$ I.

single administration of antidepressant drugs, including desipramine, a norepinephrine-reuptake inhibitor, has no effect on BDNF mRNA expression in hippocampus (Nibuya et al, 1995; Coppell et al, 2003). Our conflicting finding that desipramine decreases BDNF mRNA expression in the CA1 and the dentate gyrus may be explained by slight differences in methodology. Nibuya et al (1995) performed Northern blot analysis on the entire hippocampus, rather than examining regions of hippocampus, and Coppell et al (2003) used a lower dose of $10 \mathrm{mg} / \mathrm{kg}$ desipramine and killed animals $4 \mathrm{~h}$ after injection, which might explain the slight variation in our results. Coppell et al (2003) did report that other antidepressants including the selective serotonin reuptake inhibitors, fluoxetine, sertraline, and paroxetine, and the monoamine oxidase inhibitor, tranylcypromine, decreased BDNF mRNA levels in the dentate gyrus acutely. Fluoxetine was also shown to decrease BDNF mRNA in the CA1 and the CA3. These data along with our findings indicate that acute antidepressant treatment can decrease BDNF mRNA levels in hippocampus. We also found that desipramine decreased BDNF mRNA expression in frontal cortex, which to our knowledge has not been examined previously.

In addition, this is the first report of the acute effects of the dopamine-reuptake inhibitor, bupropion, on BDNF mRNA levels. Bupropion had no effect on BDNF mRNA 


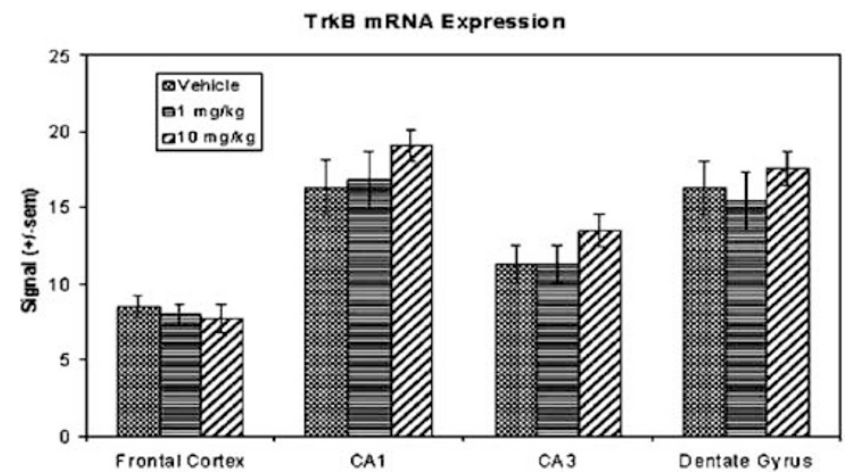

Figure 4 TrkB mRNA expression. Quantification of TrkB mRNA signal in frontal cortex and CAI, CA3, and dentate gyrus of hippocampus. Data was obtained from photomicrographs from $X$-ray films exposed for 5 days after in situ hybridization with the antisense CRNA probe to rat TrkB mRNA. Data are expressed at mean \pm SEM. There was no significant effect of treatment with I or $10 \mathrm{mg} / \mathrm{kg}(+) B W 373$ U86 s.c. on TrkB mRNA expression in any brain region examined.

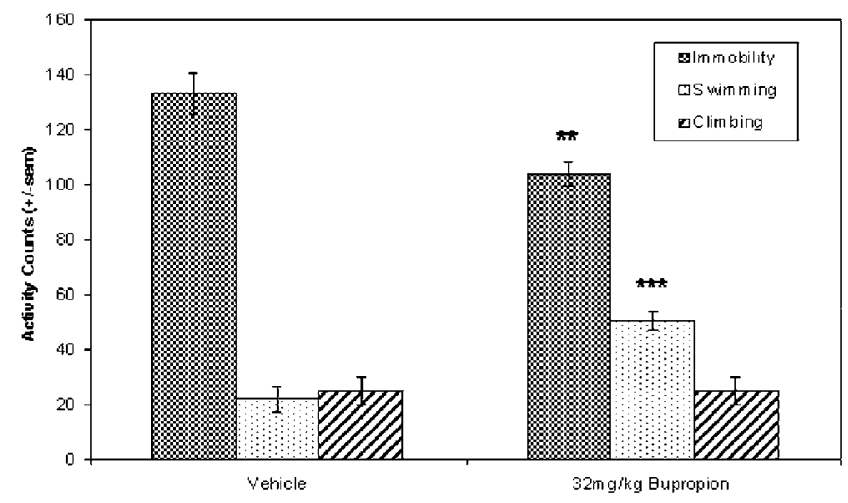

Figure 5 Bupropion decreases immobility in the forced swim test. Effect of $32 \mathrm{mg} / \mathrm{kg}$ bupropion on counts of immobility, swimming, and climbing behaviors for the total 15 min forced swim test. Bupropion significantly decreased immobility and increased swimming behaviors compared to controls, ${ }^{*} * P<0.01$, **** $P<0.001$

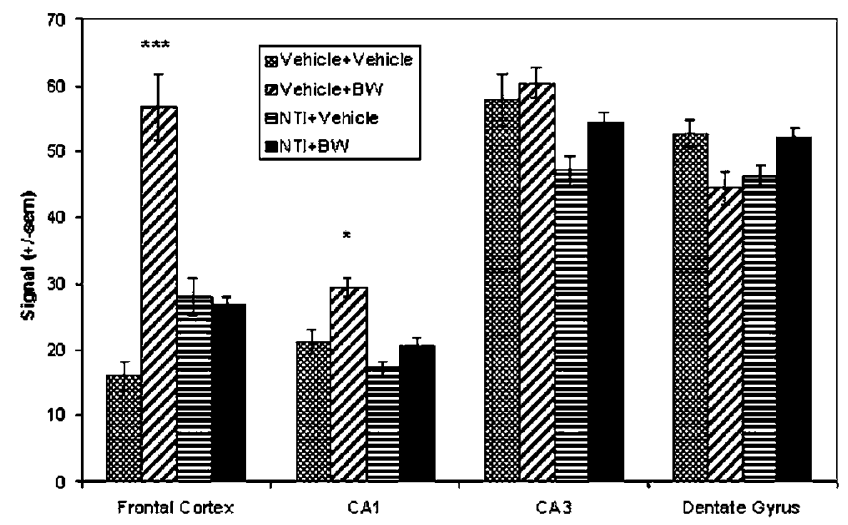

Figure $6 \mathrm{NTI}$ prevents (+)BW373U86-induced BDNF mRNA increases. Effect of $10 \mathrm{mg} / \mathrm{kg}$ naltrindole (NTI) s.c. on BDNF mRNA expression induced by $10 \mathrm{mg} / \mathrm{kg}(+) B W 373 \cup 86$ (BW). Data are expressed as mean BDNF signal \pm SEM in the frontal cortex, CAI, CA3, and dentate gyrus. BW significantly increased BDNF mRNA expression in the frontal cortex and in the CAI of hippocampus and this effect was blocked by NTI, *P $<0.05$, **** $P<0.001$.

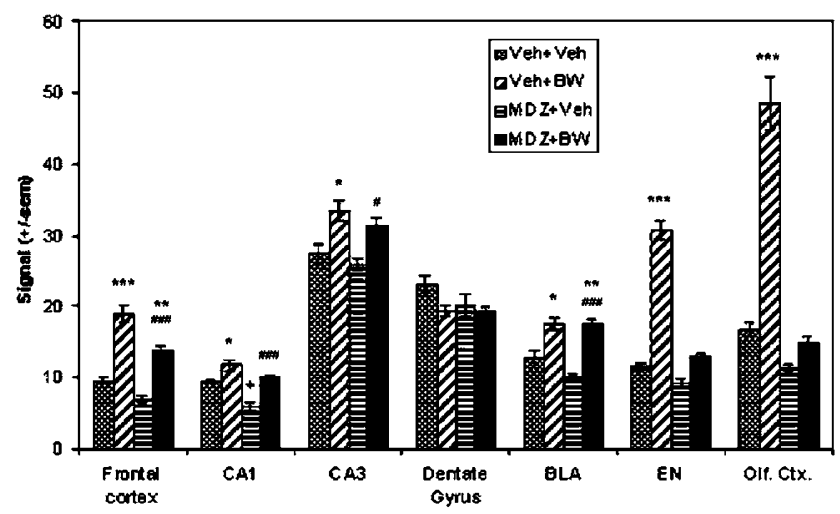

Figure 7 Effects of midazolam on (+)BW373U86-mediated increases in BDNF mRNA expression. Effect of $0.5 \mathrm{mg} / \mathrm{kg}$ midazolam (MDZ) on BDNF mRNA expression induced by $10 \mathrm{mg} / \mathrm{kg}$ BW. Data are expressed as mean BDNF signal \pm SEM in the frontal cortex, CAI, CA3, dentate gyrus, BLA, EN, and Olf. Ctx. BW significantly increased BDNF mRNA expression in the frontal cortex, CAI, CA3, BLA, EN, and Olf. Ctx. MDZ did not block increases in BDNF mRNA expression compared to vehicle controls in frontal cortex or $B L A, * P<0.05$, *** $P<0.01$, **** $P<0.00$ I. BW significantly increased BDNF mRNA expression over MDZ-treated controls in frontal cortex, CAI, CA3, and BLA, ${ }^{\#} P<0.05,{ }^{\# \#} P<0.00$ I. MDZ significantly decreased $\mathrm{BDNF}$ mRNA expression compared to vehicle controls in CAI, ${ }^{+} P<0.001$.

expression in frontal cortex, but did significantly decrease BDNF mRNA expression in the CA1 and dentate gyrus regions of hippocampus. Chronic bupropion administration has not been evaluated for its effects on BDNF or TrkB mRNA expression, but the dopamine releasing agent, amphetamine, has been shown to increase BDNF mRNA in the basolateral amygdala, piriform cortex, and paraventricular nucleus of the hypothalamus when given for 5 days (Meredith et al, 2002). On the other hand, chronic cocaine (a monoamine-reuptake inhibitor) was shown to have no effect on BDNF or TrkB mRNA expression in hippocampus by Northern blot (Nibuya et al, 1995). Therefore, a study of chronic effects will need to be conducted to determine if bupropion has a similar profile to other antidepressants when given chronically.

$\delta$-Opioid receptor agonists have similar properties to dopamine-reuptake inhibitors like bupropion, including dopamine-receptor-dependent increases in locomotor activity. Spina et al (1998), found that increases in locomotion and stereotypies produced by the $\delta$-opioid receptor agonists SNC80 and BW373U86 were blocked by the D1 receptor antagonist SCH 23390 and were partially blocked by the D2/ D3 antagonist raclopride. In addition, Pinna and Di Chiara (1998) found that BW373U86 and SNC80 enhanced the effects of D1 and D2 receptor agonists. Despite the evidence for $\delta$-opioid receptor/dopamine interactions, acute $(+)$ BW373U86 increased BDNF mRNA expression in several regions, while bupropion decreased or had no effect on BDNF mRNA levels, indicating that $\delta$-opioid receptormediated increases in BDNF mRNA expression are not due to increases in dopaminergic activity. In addition, $(+)$ BW373U86 does not increase BDNF mRNA expression through noradrenergic mechanisms, as desipramine also had opposite effects on BDNF levels. 

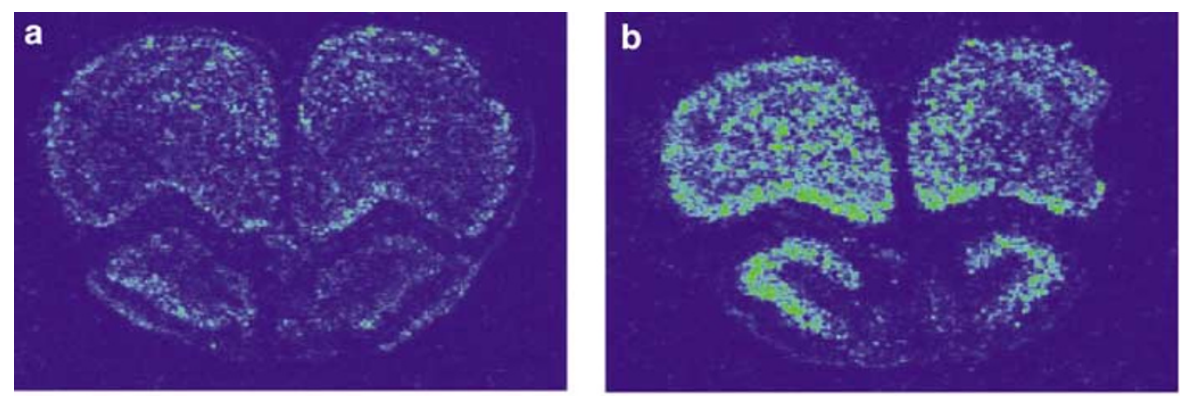

C

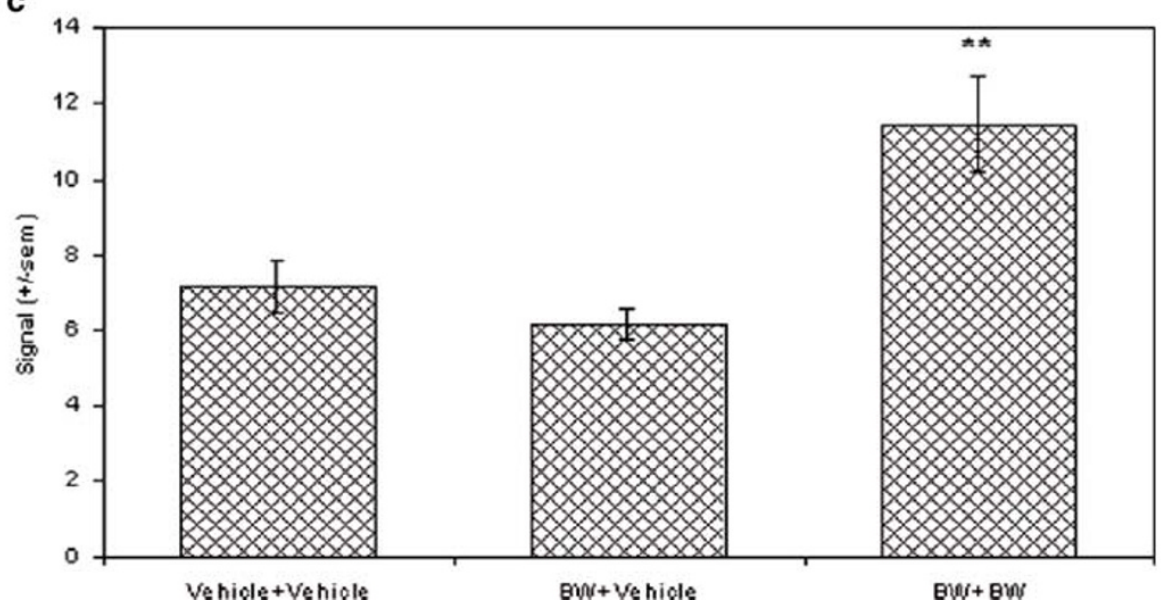

Figure 8 Incomplete tolerance to BDNF mRNA increases in frontal cortex. (a-b) Photomicrographs from X-ray films exposed for 14 days after in situ hybridization with the antisense cRNA probe to rat BDNF mRNA. Sections shown are through the frontal cortex. (a) Section from an animal treated with two injections of vehicle separated by $24 \mathrm{~h}$. (b) Section from an animal treated with two injections of $10 \mathrm{mg} / \mathrm{kg}(+)$ ) BW373U86 (BW) separated by $24 \mathrm{~h}$. (c) Quantification of BDNF mRNA signal in the frontal cortex expressed as mean \pm SEM. Animals were given two injections $24 \mathrm{~h}$ apart of vehicle day I/vehicle day 2; $10 \mathrm{mg} / \mathrm{kg}$ BW day $1 /$ vehicle day 2; or $10 \mathrm{mg} / \mathrm{kg}$ BW day $1 / 10 \mathrm{mg} / \mathrm{kg}$ BW day 2 . A second injection of $10 \mathrm{mg} / \mathrm{kg}$ BW significantly increased BDNF $\mathrm{mRNA}$ expression over control, *** $<0.0 \mathrm{I}$. Expression was less than that seen with a single injection of $10 \mathrm{mg} / \mathrm{kg} \mathrm{BW}$. BW (I0 mg/kg) did not maintain an increase in BDNF mRNA expression after $24 \mathrm{~h}$.

\section{Is Increased BDNF Activity Important for Behavioral Antidepressant Effects?}

The rapid regulation of $\mathrm{BDNF}$ mRNA indicates that $\delta$-opioid receptor activation may cause a large BDNF release or transport from neurons, particularly in frontal cortex. Shirayama et al (2002) demonstrated that an injection of BDNF directly into the hippocampal CA3 or dentate gyrus regions was sufficient to produce behavioral antidepressant effects in rats. The study did not examine whether injections into frontal cortical regions would have the same effect, but it is possible. Even so, the $\delta$-opioid receptor agonist did result in some increase of BDNF mRNA in the CA3 of hippocampus, implying that BDNF may have been released in this region and resulted in behavioral antidepressant effects.

On the other hand, desipramine and bupropion both produce antidepressant effects in the forced swim test after a single administration (Broom et al, 2002b and Figure 5), but do not increase BDNF mRNA expression, suggesting that BDNF release is not necessary for behavioral effects. However, fluoxetine and imipramine, which is closely related to desipramine, have been shown to activate (phosphorylate) TrkB receptors within $30 \mathrm{~min}$ after injection in the mouse, and TrkB activation was shown to be necessary for the behavioral effects of these drugs in the forced swim test (Saarelainen et al, 2003). Therefore, release of BDNF may still be important for behavioral antidepressant effects, but BDNF gene expression is regulated differentially across classes of drugs. $\delta$-Opioid receptor agonists may produce a greater release of BDNF resulting in more rapid changes in $\mathrm{BDNF}$ gene expression. A rapid increase in BDNF signaling may also bring about more rapid improvements in mood in humans.

Another possibility is that there is a more prolonged effect on synaptic organization and efficacy that results from increased BDNF in the various brain regions. However, protein levels were not measured in this study, so it is possible that there was not a significant increase in BDNF available to affect synaptic efficacy or organization. However, several reports indicate increased BDNF immunoreactivity or protein content in brain regions that also have increased mRNA expression (Solum and Handa, 2002; Meredith et al, 2002; Mackowiak et al, 2002; Rage et al, 2002), suggesting that BDNF mRNA is generally transcribed into protein rather than being degraded.

\section{Convulsion Independent Effects of $\delta$-Opioid Receptor Agonists}

The nonpeptidic $\delta$-opioid receptor agonists administered s.c. can produce a brief, nonlethal convulsion, at certain 
doses in rats. The convulsion is followed by a brief period of catalepsy (2-4 min), after which the animals behave normally, though with increased locomotor activity (Broom et al, 2002a and personal observations). ECS and chemical convulsants have also been shown to increase BDNF mRNA expression in a rapid manner (Nibuya et al, 1995; KatohSemba et al, 2001). It is interesting that historically chemical convulsants have been used to treat depression, and ECS remains an important therapeutic option in some patients (George et al, 2002; Remick, 2002). ECS begins to improve mood more rapidly than common pharmacological antidepressants (Kraus and Chandarana, 1997), and the speed of effect may be due to rapid changes in BDNF signaling and/or regulation of $\mathrm{BDNF}$ gene expression.

The increases in BDNF mRNA mediated by $\delta$-opioid receptor activation may simply result from the large increase in electrical activity and neurotransmitter release that occurs with a convulsion. However, the antidepressant effect of $(+)$ BW373U86 in the rat forced swim test is not dependent on the animal convulsing. Rats pretreated with the GABAergic anticonvulsant, midazolam, prior to injection of $(+)$ BW373U86 did not convulse, but demonstrated an antidepressant effect in the forced swim test (Broom et al, $2002 \mathrm{~b})$. In addition, a dose of $1 \mathrm{mg} / \mathrm{kg}(+)$ BW373U86 did not produce a convulsion, but did produce a significant increase in BDNF mRNA expression in the frontal cortex and tended to increase BDNF in the CA1 and the CA3 of hippocampus, indicating the potential to regulate $\mathrm{BDNF}$ mRNA expression independent of a convulsion.

To test this directly, midazolam was given prior to an injection of $(+) \mathrm{BW} 373 \mathrm{U} 86$, and $3 \mathrm{~h}$ later animals were killed and BDNF mRNA levels were examined. Midazolam did not block increases in BDNF mRNA expression in frontal cortex or basolateral amygdala compared to vehicle controls, and did not block $\delta$-opioid receptor-mediated increases in BDNF mRNA expression in the CA1, CA3, and endopiriform nucleus when compared to midazolamtreated controls. Midazolam alone tended to decrease BDNF mRNA expression in several brain regions, but $(+)$ BW373U86 was able to increase BDNF mRNA levels above this depressed level in most brain regions, and even beyond vehicle control levels in two brain regions. The olfactory cortex is the only region that appears to be completely dependent on the presence of a convulsion for increases in BDNF mRNA. These data are consistent with the concept that $\delta$-opioid receptor activation has a direct and rapid effect on BDNF gene regulation.

However, the amount of BDNF mRNA expression induced by $(+)$ BW373U86 when given after midazolam was significantly reduced in most brain regions, compared to $(+)$ BW373U86 given alone. Therefore, it is possible that $\delta$-opioid receptor activation continues to lead to an increase in neuronal activity, but does not produce an overt convulsion. An increase in neuronal activity may be responsible for the increases in BDNF mRNA expression, rather than being a direct result of increased $\delta$-opioid receptor activation. However, the brain regions that showed none or almost no increase in BDNF mRNA expression after midazolam and $(+)$ BW373U86, the olfactory cortex and endopiriform nucleus, are also the two regions where there are very little, if any, $\delta$-opioid receptors (Mansour et al, 1993; Cahill et al, 2001). This suggests that $\delta$-opioid receptor activation may have a direct effect on BDNF mRNA expression, and that convulsions produce an additional, $\delta$-receptor independent, increase in BDNF expression.

\section{Tolerance Development to Increases in BDNF mRNA}

Tolerance develops to several behavioral effects of $\delta$-opioid receptor agonists including convulsions, and locomotor stimulation, but not to the antidepressant effects (Broom et al, 2002b; Jutkiewicz et al, unpublished observations). Therefore, presuming that increased BDNF activity is important for the behavioral antidepressant effects, we expected to find increases in BDNF mRNA expression after repeated administration of $(+) B W 373$ U86. We found tolerance to increases in BDNF gene expression did develop in the hippocampus, basolateral amygdala, endopiriform nucleus, and primary olfactory cortex, but not in frontal cortex. In frontal cortex there was a significant increase in BDNF mRNA expression with repeated injection, though to a lesser extent than with a single administration. This is another piece of data suggesting that the frontal cortex may be a critical brain region for $\delta$-opioid receptor-mediated antidepressant behavioral effects, whereas, the olfactory cortex is only responsive to convulsions and may mediate convulsive effects. The amygdala, primary olfactory cortex, and endopiriform nucleus have been implicated in seizure propagation in amygdala kindling models of epilepsy (Loscher and Ebert, 1996). The data presented here suggest that $\delta$-opioid receptor-mediated convulsions may involve this amygdala-olfactory cortex circuit.

\section{$\delta$-Opioid Receptor Agonist Effects on TrkB mRNA}

Unlike known antidepressants, (+)BW373U86 had no effect on TrkB mRNA expression in any brain region. Other antidepressants have been shown to increase TrkB mRNA expression (Nibuya et al, 1995). However, all antidepressants, except for ECS, were given for 21 days before a regulation of the $\operatorname{TrkB}$ gene was observed. In the experiments reported here, animals were given a single injection and only $3 \mathrm{~h}$ passed before being killed and subsequent measurement of mRNA levels. It is possible that TrkB receptor expression is regulated more slowly than $\mathrm{BDNF}$, and if the animals were killed at a later time-point, a difference in TrkB mRNA levels would be observed.

\section{Neuroprotective Implications for $\boldsymbol{\delta}$-Opioid Receptor Agonists}

The finding that $\delta$-opioid receptor agonists increase BDNF gene expression across several brain regions supports the idea that these compounds would have potential as neuroprotective agents. Tsao and $\mathrm{Su}$ (2001) found that DADLE, a stable enkephalin analog, blocked apoptosis induced by the protein Bax, a member of the Bcl-2 family of proteins, which is inhibited through the action of neurotrophins (Yuan and Yankner, 2000). The antiapoptotic effect of DADLE may be mediated through $\delta$-opioid receptor-induced activation of BDNF. Likewise, $\delta$-opioid receptor agonists prolong survival in mice undergoing lethal hypoxia (Bofetiado et al, 1996; Mayfield and D'Alecy, 
1994), which may also be mediated by increased BDNF activity. In addition, $\delta$-opioid receptor agonists are reported to reverse akinesias and catalepsy produced in animal models of Parkinson's disease (eg Hille et al, 2001). BDNF has also been shown to have positive effects on symptoms of Parkinson's disease (Wang et al, 2002), implying another potential link between the two systems. Therefore, $\delta$-opioid receptor agonists represent a potential target for rapid regulation of BDNF, and possibly other neurotrophic factors, that could be useful in the treatment of several disorders including depression.

\section{ACKNOWLEDGEMENTS}

The authors thank Prasanth Navarasala for help with image analysis. The research was supported by USPHS Grants DA00254, DA07281, DA13386, and MH42251.

\section{REFERENCES}

Bishop MJ, McNutt RW (1995). An efficient synthesis of the benzhydrylpiperazine delta opioid agonist (+)BW373U86. Bioorg Med Chem Lett 5: 1311-1314.

Bofetiado DM, Mayfield KP, D’Alecy LG (1996). Alkaloid delta agonist BW373U86 increases hypoxic tolerance. Anesth Analg 82: 1237-1241.

Broom DC, Jutkiewicz EM, Folk JE, Traynor JR, Rice KC, Woods JH (2002a). Nonpeptidic delta-opioid receptor agonists reduce immobility in the forced swim assay in rats. Neuropsychopharmacology 26: 744-755.

Broom DC, Jutkiewicz EM, Folk JE, Traynor JR, Rice KC, Woods $\mathrm{JH}$ (2002b). Convulsant activity of a non-peptidic delta-opioid receptor agonist is not required for its antidepressant effects in Sprague-Dawley rats. Psychopharmacology 164: 42-48.

Cahill CM, McClellan KA, Morinville A, Hoffert C, Hubatsch D, O'Donnell D et al (2001). Immunohistochemical distribution of delta opioid receptors in the rat central nervous system: evidence for somatodendritic labeling and antigen-specific cellular compartmentalization. J Comp Neurol 440: 65-84.

Comer SD, Hoenicke EM, Sable AI, McNutt RW, Chang K-J, DeCosta BR et al (1993). Convulsive effects of systemic administration of the delta opioid agonist BW373U86 in mice. J Pharmacol Exp Ther 215: 127-134.

Coppell AL, Pei Q, Zetterstrom TSC (2003). Bi-phasic change in BDNF gene expression following antidepressant drug treatment. Neuropharmacology 44: 903-910.

Duman RS (2002). Synaptic plasticity and mood disorders. Mol Psychiatry 7: S29-S34.

Duman RS, Heninger GR, Nestler EJ (1997). A molecular and cellular theory of depression. Arch Gen Psychiatry 54: 597-606.

Duman RS, Malberg J, Nakagawa S, D'Sa C (2000). Neuronal plasticity and survival in mood disorders. Biol Psychiatry 48: 732-739.

Filliol D, Ghozland S, Chluba J, Martin M, Matthes HWD, Simonin F et al (2000). Mice deficient for delta and mu-opioid receptors exhibit opposing alterations of emotional responses. Nat Genet 25: 195-200.

George MS, Nahas Z, Li X, Kozel FA, Anderson B, Yamanaka K et al (2002). Novel treatments of mood disorders based on brain circuitry (ECT, MST, TMS, VNS, DBS). Semin Clin Neuropsychiatry 7: 293-304.

Hille CJ, Fox SH, Maneuf YP, Crossman AR, Brotchie JM (2001). Antiparkinsonian action of a delta opioid agonist in rodent and primate models of Parkinson's disease. Exp Neurol 172: 189-198.
Hong EJ, Rice KC, Calderon S, Woods JH, Traynor JR (1998). Convulsive behavior of nonpeptide delta opioid ligands: comparison of SNC80 and BW373U86 in mice. Analgesia 3: 269-276.

Isackson PJ, Huntsman MM, Murray KD, Gall CM (1991). BDNF mRNA expression is increased in adult rat forebrain after limbic seizures: temporal patterns of induction distinct from NGF. Neuron 6: 937-948.

Katoh-Semba R, Takeuchi IK, Inaguma Y, Ichisaka S, Hata Y, Tsumoto $\mathrm{T}$ et al (2001). Induction of brain-derived neurotrophic factor by convulsant drugs in the rat brain: involvement of region-specific voltage-dependent calcium channels. J Neurochem 77: 71-83.

Kraus RP, Chandarana P (1997). Say, are you psychiatrists still using ECT? Can Med Assoc J 157: 1375-1377.

Loscher W, Ebert U (1996). The role of the piriform cortex in kindling. Prog Neurobiol 50: 427-481.

Mackowiak M, O’Neill MJ, Hicks CA, Bleakman D, Skolnick P (2002). An AMPA receptor potentiator modulates hippocampal expression of BDNF: an in vivo study. Neuropharmacology 43: $1-10$.

Mansour A, Thompson RC, Akil H, Watson SJ (1993). Delta opioid receptor mRNA distribution in the brain: comparison to delta receptor binding and proenkephalin mRNA. J Chem Neuroanatomy 6: 351-362.

Mayfield KP, D'Alecy LG (1994). Delta-1 opioid agonist acutely increases hypoxic tolerance. J Pharmacol Exp Ther 268: 683-688.

McAllister AK, Katz LC, Lo DC (1999). Neurotrophins and synaptic plasticity. Annu Rev Neurosci 22: 295-318.

Meredith GE, Callen S, Scheuer DA (2002). Brain-derived neurotrophic factor expression is increased in the rat amygdala, piriform cortex, and hypothalamus following repeated amphetamine administration. Brain Res 949: 218-227.

Middlemas DS, Lindberg RA, Hunter T (1991). TrkB, a neural receptor protein-tyrosine kinase: evidence for a full-length and two truncated receptors. Mol Cell Biol 11: 143-153.

Nibuya M, Morinobu S, Duman RS (1995). Regulation of BDNF and TrkB mRNA in rat brain by chronic electroconvulsive seizure and antidepressant drug treatments. J Neurosci 15: 7539-7547.

Pinna A, Di Chiara G (1998). Dopamine-dependent behavioural stimulation by non-peptide delta opioids BW373U86 and SNC80: 3. Facilitation of D1 and D2 responses in unilaterally 6hydroxydopamine-lesioned rats. Behav Pharmacol 9: 15-21.

Rage F, Givalois L, Marmigere F, Tapia-Arancibia L, Arancibia S (2002). Immobilization stress rapidly modulates BDNF mRNA expression in the hypothalamus of adult male rats. Neuroscience 112: 309-318.

Remick RA (2002). Diagnosis and management of depression in primary care: a clinical update and review. Can Med Assoc J 167: $1253-1260$.

Saarelainen T, Hendolin P, Lucas G, Koponen E, Sairanen M, MacDonald E et al (2003). Activation of the TrkB neurotrophin receptor is induced by antidepressant drugs and is required for antidepressant-induced behavioral effects. $J$ Neurosci 23: 349-357.

Shirayama Y, Chen AC-H, Nakagawa S, Russell DS, Duman RS (2002). Brain-derived neurotrophic factor produces antidepressant effects in behavioral models of depression. J Neurosci 22: 3251-3261.

Siuciak JA, Lewis DR, Wiegand SJ, Lindsay RM (1997). Antidepressant-like effect of brain-derived neurotrophic factor (BDNF). Pharmacol Biochem Behav 56: 131-137.

Solum DT, Handa RJ (2002). Estrogen regulates the development of brain-derived neurotrophic factor mRNA and protein in the rat hippocampus. J Neurosci 22: 2650-2659.

Spina L, Longoni R, Mulas A, Chang K-J, DiChiara G (1998). Dopamine-dependent behavioural stimulation by non-peptide 
delta opioids BW373U86 and SNC80: 1. Locomotion, rearing and stereotypies in intact rats. Behav Pharmacol 9: 1-8.

Tejedor-Real P, Mico JA, Smadja C, Maldonado R, Roques BP, Gibert-Rahola J (1998). Involvement of delta-opioid receptors in the effects induced by endogenous enkephalins on learned helplessness model. Eur J Pharmacol 354: 1-7.

Tsao L-I, Su T-P (2001). Hibernation-induction peptide and cell death: [D-Ala, D-Leu]enkephalin blocks Bax-related apoptotic processes. Eur J Pharmacol 428: 149-151.
Vaidya VA, Duman RS (2001). Depression-emerging insights from neurobiology. Br Med Bull 57: 61-79.

Wang ZH, Ji Y, Shan W, Zeng B, Raksadawan N, Pastores GM et al (2002). Therapeutic effects of astrocytes expressing both tyrosine hydroxylase and brain-derived neurotrophic factor on a rat model of Parkinson's Disease. Neuroscience 113: 629-640.

Yuan J, Yankner BA (2000). Apoptosis in the nervous system. Nature 407: 802-809. 